\title{
The Analytic Possibilities of 'Culture' in a Post-prison Context
}

\author{
Diana Johns, RMIT University/University of Melbourne
}

Conference Sub-theme: Penal Policy and Punishment

\begin{abstract}
This paper is focused on the use and usefulness of 'culture' as an analytical tool, in the context of prisoners' return to the community. Whereas the analytic dimensions of the culture concept have been explored in anthropological circles, its criminological applications have been limited. While the growth of 'cultural criminology' signifies a resurgent interest in ethnography, subjectivity, lived experience and the phenomenological, for instance, it can be argued that its concept of culture lacks explanatory or analytical power. This paper considers the analytic possibilities of 'culture' as a tool for uncovering aspects of the postimprisonment experience. It draws on interviews with released prisoners and post-release support workers, conducted for $\mathrm{PhD}$ research on the post-release experience of men in Victoria, to illustrate how culture applied in this way can illuminate processes underpinning and constituting the cycle of reimprisonment, or what Halsey (2006) has termed the 'reincarceration assemblage'. Seeing culture as both a 'product and producer' (Sampson and Bean 2006) of this assemblage reveals elements which contribute to the continuation of the cycle, and which can counteract efforts - on the part of ex-prisoners themselves and society more broadly - towards reintegration and reduced reoffending. A cultural perspective can thus provide a way of understanding men's experience of getting out and staying out of prison, and how penological thinking may make use of such a lens.
\end{abstract}

\section{Introduction}

Offenders emerge from prison afraid to trust, fearful of the unknown, and with a vision of the world shaped by the meaning that behaviours had in the prison context. ... [T] he system we have designed to deal with offenders is among the most iatrogenic in history, nurturing those very qualities it claims to deter. (Miller 2000 in Liebling and Maruna 2005: 1)

In a recent news article in the Hobart Mercury (Smith 2013), 'James', a long-term prisoner and resident at the newly opened transitional units at Risdon Prison, makes plain why prisoners need help to adjust to life on the outside: 'You want people to go out better, not worse.' Yet, as Miller (2000) observes, prisoners often emerge from prison marked by the very qualities the correctional system is meant to 'correct', qualities that can make life in the community unsustainable and reimprisonment inevitable. Striking is that since the birth of the modern prison, despite two hundred years of penal advancement and knowledge, so little has changed: in 1831, in France, 38\% of men were reimprisoned following their release (Foucault 1979); today, in Australia, the figure is almost identical (ABS 2010).

The hardening, damaging effects of imprisonment and its endemic cultural codes are well established. That the culture of the prison leaks out into the post-prison sphere is axiomatic. Yet analyses of the factors associated with recidivism and cyclic imprisonment frequently leave culture, and the cultural components of prisoners' experience, unexamined. This paper critically 
engages with the idea of culture as a useful tool for understanding men's post-release experience and how and why so many become ensnared in cycles of reimprisonment. The focus is on men in particular since they comprise the majority of prisoners released and hence the bulk of the 'post-release problem'. It begins with the concept of 'culture' which, as an analytic device, has been embraced in anthropological circles yet remains underdeveloped in criminology. A distinction is drawn between 'culture' as a socially bounded frame and 'culture' as a meaning-making 'toolkit'. The ensuing section explains the cultural lens applied in the $\mathrm{PhD}$ research on which this paper draws, and briefly outlines the study. Finally, research findings illustrate the analytic possibilities of culture in a post-prison context.

\section{Conceptualising Culture}

Culture is a complicated and contested term. It has been defined, rejected and elaborated since its earliest anthropological formulation as that complex whole which includes knowledge, belief, art, morals, law, custom, and any capabilities and habits acquired by man as a member of society' (Tylor 1871 in Eagleton 2000: 34). Notwithstanding an ongoing lack of consensus, the anthropological concept of culture as a way of life peculiar to a social group - the collected ideas and habits learned, shared and transmitted; its material and symbolic aspects - has seeped into other disciplines as a nascent theoretical concept and burgeoning analytical approach.

Criminology, however, has been slow on the uptake. Until very recently, penological research conceived cultural forms narrowly, if at all (Garland 2006). The growth of 'cultural criminology' (e.g. Ferrell 1999; Hayward and Young 2004; Ferrell, Hayward and Young 2008) embodies a resurgent interest in ethnography, lived experience, and the phenomenological. It foregrounds 'cultural' aspects of crime and its control: 'the subjective, affective, embodied, aesthetic, material, performative, textual, symbolic and visual relations of space ... recognising that the settings of crime are ... relational, improvised, contingent, constructed and contested' (Campbell 2012 in Hayward 2012: 450). Yet O’Brien (2005) argues cultural criminology undertheorises its concept of culture and thus lacks explanatory or analytical power, indeed that it is political rather than analytical in orientation. Cultural criminology then, despite its promise, offers little in the way of analytic tools.

So what are the analytical possibilities of 'culture' as a concept? Critics argue that 'culture is essentialised, reified, and overhomogenised' (Brumann 2004: 199). It is either conceptualised so broadly as to render it meaningless, or so narrowly as to limit its theoretical validity; it appears 'torn between an empty universalism and a blind particularism' (Eagleton 2000: 44). Rational choice theorists have rejected cultural accounts as 'tautological, untestable, or beside the point' (Wedeen 2002: 714). Sewell (2004: 202), however, draws an important distinction between the use of the plural form ('cultures'), describing 'concrete and bounded worlds of beliefs and practices', and the singular concept denoting a 'semiotics of social life'. Sewell argues that it is the elision of these two distinct meanings of culture that causes confusion and gives rise to criticism of the latter concept based on the shortcomings inhering in the former. For instance, Larmour (2007: 228) refers to three common misuses of culture as a concept: as an 'uncaused cause'; as an 'explanation of last resort'; and as a 'veto on comparison', which seem to illustrate Sewell's contention. Certainly culture used in this way appears 'outmoded and unhelpful' (Wedeen 2002: 714). Sewell's distinction is therefore useful to differentiate culture as an analytic concept from its use as a 'totalising term' (Garland 2006: 423).

Prison culture epitomises this 'totalising' form: the closed setting where hegemonic masculine norms are exaggerated into extreme models of hypermasculinity; where violence and intimidation become normalised, legitimised. The ways of being that Miller (2000) describes 'afraid to trust, fearful of the unknown' - are entrenched in prison culture. This conception of culture, as located within a particular bounded set of social relations, provides rich descriptive 
insight. It is limited, however, in its capacity to explain how culture functions. Miller's 'world shaped by the meaning that behaviours had in the prison context' gives an important clue as to how culture might take on an analytic function; how we might think about culture in terms of meaning and behaviour.

\section{A Culture-in-action, Semiotic-practical Lens}

Building on Sewell's 'semiotics of social life' definition, Wedeen (2002: 720) argues for a conceptualisation of culture as 'the practices of meaning-making through which social actors attempt to make their world coherent'. Cultural analysis from this perspective involves studying the relations between peoples' practices and their signifying systems of language and other symbols, an approach characterised as 'semiotic practices' (Wedeen 2002: 714). Culture in these terms refers to what people do, how those things are invested with meaning, and how those meanings produce effects. Thus culture refers not to essential values or particular traits isolating one group from another; rather, a cultural view obliges 'an account of how symbols operate in practice, why meanings generate action, and why actions produce meanings, when they do' (Wedeen 2002: 720). This approach builds on Swidler's (1986) 'culture-in-action' model.

Swidler (1986: 273) views culture as a 'toolkit' - a 'repertoire' of habits, skills, and styles which shape people's problem-solving and decision-making, and from which they construct 'strategies of action'. 'Strategy' here means 'a general way of organising action' rather than a conscious plan (Swidler 1986: 277). Culture is causative in that it 'shapes the capacities from which such strategies of action are constructed' (Swidler 1986: 277). Importantly in the context of postprison experience, Swidler (1986: 278) distinguishes between how culture affects action in 'settled lives' and 'unsettled lives' in terms of sustaining continuities and constructing new patterns. In 'unsettled lives', she explains, '[p]eople developing new strategies of action depend on cultural models to learn styles of self, relationship, cooperation [and] authority', and that these models 'make explicit demands in a contested cultural arena' (Swidler 1986: 279). It is this contested space that emerges so palpably in sociological accounts of the prison world. The initial experience of imprisonment and adaptation to prison life may be viewed in this way, as a period during which competing ways of organising behaviours contend for dominance (the prison regime, officers' culture, prisoners' social hierarchies, individual histories and identity), and new strategies of action are constructed from an available repertoire of 'symbols, rituals, stories, and guides to action' (Swidler 1986: 77).

In contrast, settled cultures claim 'authority of habit [and] normality' yet 'constrain action by providing a limited set of resources out of which individuals and groups construct strategies of action' (Swidler 1986: 281). In prison, for instance, 'masculinity resources are severely limited' (Karp 2010: 66). The process of settling into prison life or into a 'prisoner' identity can similarly be seen as constraining future action, due to what Swidler calls the "high costs of cultural retooling' (Swidler 1986: 284) involved in crafting new ways of being, particularly when postrelease cultural resources are limited; if an ex-prisoner's friends and family share habits, skills and styles oriented towards violence and drug abuse, for example. Thus Swidler's culture-inaction model can explain how culture influences behavioural choices in prison, as well as ways of being upon release and return to community.

Wedeen's (2002) semiotic-practical approach clearly draws on Swidler's (1986) formulation of the relations between meaning and action. From this relational perspective, culture is seen as:

... an inter-subjective organising mechanism that shapes unfolding social processes and that is constitutive of social structure ... [C]ulture is simultaneously an emergent product and producer of social organisation, interaction, and hence structure. (Sampson and Bean 2006: 27) 
To focus on meanings (via language and symbols) and how they relate to behaviour (practices) is useful because it emphasises the observable. Further, it enables analysis of the relationship between 'narratives of identification and everyday activities' (Wedeen 2002: 724) which, if left uninterrogated, serve to perpetuate themselves. This works on a micro (prisoner) and macro (societal) level, in what Arrigo and Milovanovic (2009: 101) describe as 'the coproduction of penological reality'. In this way culture is seen as cause (producer) and effect (product) of the carceral assemblage. Taking up Garland's (2006: 438) challenge to 'show how culture relates to conduct' by examining how meanings relate to actions allows insight into how this process unfolds.

\section{The Study}

This cultural approach forms a key theoretical component of the $\mathrm{PhD}$ research on which this paper draws ${ }^{1}$. The study sought to qualitatively map men's subjective experience of release from prison in Victoria, by interviewing released prisoners and post-release support workers. The Victorian Department of Justice funds 'Link Out', and its Indigenous equivalent, 'Konnect', which offer twelve months intensive post-release support to prisoners deemed at high risk of reoffending post-release. The agencies delivering these programs were the starting point for the snowball sampling strategy employed. Link Out and Konnect workers were briefed about the study and invited to recruit voluntary participants. Other services identified during the research process included WISE Employment's Ex-offender Program and Five8, a community-based restorative approach to building 'micro-communities' of support around individual prisoners. Workers in these programs were included in the sample. Released prisoners were recruited through the workers, word of mouth, and flyers in local employment agencies. Twelve released prisoners and fourteen workers were interviewed. The ex-prisoner participants (only) were offered a twenty dollar Coles voucher to acknowledge their participation.

Semi-structured in-depth interviews were conducted individually, face-to-face, in settings that were familiar and convenient to participants. Interviews were transcribed verbatim and analysed phenomenographically. This involved careful reading and re-reading of the interviews to gather the range of qualitatively different ways of understanding and experiencing the phenomenon of release from prison. The conceptions and ways of experiencing were organised, through subsequent aggregation of the data, into 'categories of description' which encapsulated the various ways of experiencing across the sample. The aim of this methodological approach is to capture variation in the collective, rather than individual, experience of a phenomenon (Trigwell 2006), and to portray relationships between conceptions and experience. Illustrative quotes from the data attest to the categories and themes being rooted in participants' own words ${ }^{2}$ and understandings. Thus the focus is firmly on the subjective and the relational, a logic connecting phenomenography to the study's cultural lens.

\section{Findings}

So what can a culture-in-action model of semiotic-practices reveal about the effects of imprisonment on post-release experience? Two themes emerging from the research findings are illustrative. Firstly, the data reveal that there is an embodied way of being an ex-prisoner. A set of habits and acculturations which manifest in physicality: a man's walk, his posture; his way of observing those around him without looking at them; the rolling of a cigarette. Indeed, smoking a particular brand of tobacco is indicative of how prison habits persist post-release as symbols of a prison-inflected identity:

They'll roll cigarettes like they are still in prison, like pencil thin. They will smoke a particular brand of tobacco called White Ox that everyone smokes that has ever been in jail ... they all smoke the one type of tobacco. (SW08) 
The men interviewed attest to the universality of ' $O x$ ' as prison tobacco, and how it identifies people as having been inside. As well as its strength - 'it'd be milder smoking tree bark ... and gum leaves, god it nearly knocked me out!' (RP21) - and hence its addictive quality, cigarette smoking represents a punctuating rhythm in the daily routine of prison life, a physical and psychological habit which - through frequent repetition - becomes entrenched. As RP21 recounts:

I tried to stop smoking when I was in there and I gave that up for a month, and that was just torture, because that's all you've got in there is coffee and cigarettes ... [Are you still smoking?] Yes, guess what, I'm smoking this stupid pouch [of] White Ox, yeah, that's what I did when I got paid, I bought two pouches of that, and I bought a couple of papers and four train tickets ...

Implying it is one of his daily necessities - along with newspapers and train tickets - RP21 links smoking Ox to prisoner ways of being which, despite 'trying to move away from that' and admitting 'cringing', is a hard habit to break:

I'm on the outside and I'm smoking whatever it is mild or something, all these people smoking Super Mild, Ultra Mild, and they go to prison and everyone's making these [thin 'roll-your-owns' with 0x] ... you can get [other brands] ... [but people] say if you have this it's stronger, and you get used to it, and you don't even want another cigarette as quickly. I said Christ I don't need a cigarette for six hours after that one! I said I'd be in an iron lung before I have one of these again! ... But yeah that's about the only thing that I've got a prison culture on me, as much as I cringe ... yeah I don't have to buy Ox, I don't know why I keep buying it, I think just out of habit ...

Though RP21 shielded himself from the absorption of prison mores or the development of a prison identity through his sense of passing through, of never belonging in prison, he nevertheless took on the habit of smoking $0 x$, without really being aware of how or why.

Just as prison tattoos inscribe the skin, ways of being in prison can thus permeate thinking and inhabit prisoners' bodies. As SW08 describes:

... when the guys come out of prison and they meet up here for instance they will often pace up and down in their little basketball yard at the back, have you ever seen men in a prison walking up and down just doing laps? They will go this way, and then they turn right, and then go back and then turn left and go that way, and you see them pacing like that, and they won't even know they're doing it. They are conditioned to that sort of way of communicating with one another. They'll pace up and down; they'll dress like they are still in prison. They'll carry themselves like they're still in prison.

Evoked is a robotic return to the way physical space is navigated and traversed in prison, as though its spatial patterns are - like a tobacco habit - ingrained through repetition. Though these physical cultural imprints are subtle, minor, they nevertheless signify the degree to which prison ways of being leak out into the post-prison world. Other ways are more extreme in their intensity of experience and destructive potential.

Years spent in and out of prison are shown to limit men's cultural resources to those available within the prison setting. Violence is normalised, indeed honed as a skill. 'Friends' are prison 'associates', 'jailbirds' and 'druggies'. Adapting to prison life clearly involves the forging of a prison identity - 'you're a prisoner and you're one of the boys' (SW12) - and the destabilising of men's pre-prison identity, their social place. While different prison-selves manifest - arising 
from individual circumstances, causes and conditions - a common thread links their emergence into post-prison light: 'when they get out they don't have a [social] place ... and they lose whatever sense of self they had ... which can cause that out of control spiral' (SW09). This is conceived by workers as relating to the length of time spent in prison: 'probably up to twelve months is not so bad, but when it gets into two, three years, it becomes a little more freaky for them' (SW13); yet the men's pre-prison sense of self appears to shape the degree to which their prison identity becomes 'ingrained' (RP07).

RP07, for example, has a clearly demarcated prison identity and describes the choosing and crafting of implements his prison role entails:

I prefer ... [to] snap open a razor blade and melt the blades into a toothbrush, shave the toothbrush bit off and melt the blades into it, melt about three or four blades in, all different ways, so no matter which way you get them ... it will open up in two spots so it's harder for 'em to sew back together, and leaves a bigger scar, and you get 'em straight down the face and that way everyday they look in the mirror they know that it was you who done it.

RP07 conveys a sense of asserting his prison identity through his attack strategy, as though by leaving his mark on his victim, so 'they know it was you who done it', his reputation of being 'a bit fucked in the head', and hence not to be messed with, is underscored.

Notwithstanding the matter-of-fact way RP07 relates this experience, implying its normality, he also recognises that - while functional in prison - such behaviour is dysfunctional and unacceptable outside: 'that's the type of thing that I bring outside with me, and then I've gotta try and not be like that out here, you know?' He describes how being 'like that' is 'just ingrained in me now', implying that violence is an automatic response:

... it's like ... over twenty bucks the other day I was gonna go to my mate's place and kick his front door in, with three other people, and ... just wreck him over twenty bucks, man, you know? (RP07)

His sense of dismay at being 'like that' is palpable. Yet the costs of 'cultural retooling' (Swidler, 1986) for RP07 are high, possibly too high to contemplate. Without any 'straight friends', with limited family support, and only a case worker to rely on, his social and cultural resources are limited. And in his 'unsettled' post-release life, where cultural models compete in a 'contested cultural arena', the familiarity of his 'old life' and his 'druggie mates' vie for 'authority of habit [and] normality' (Swidler, 1986: 279). A battle is evoked for 'crims' like RP07, who:

... have had their whole life destroyed when they were kids, ... they've been trained into this is what your life will be more or less and then having to battle every time they turn around, battle and battle and battle... (RP18)

\section{Conclusion}

These themes illustrate how meanings and behaviours which function in a prison context can shape and inflect men's post-prison experience, their identity and interactions. In this way, as Sampson and Bean (2006) contend, culture can constitute social structure, manifesting in the constraints which militate against ex-prisoners' post-release integration. Whether these take the form of subtle cultural imprints that are hard habits to break, and which shadow a man's sense of self. Or habits, skills and styles - such as prison cultural norms of violence - learned, honed, incorporated and which mark out a prisoner identity. Clearly, 'there is continuity between what occurs within the prison environment and what occurs outside of it' (Arrigo and Milovanovic 2009: 39). A cultural perspective provides a way of understanding this continuity and its impact on men's experience of getting out and staying out of prison. 
1 This PhD was undertaken as part of the Australian Prisons Project (www.app.unsw.edu.au), supported by an Australian Research Council Discovery Program grant (DP0877331).

2 The speakers are designated 'RP' ('released prisoner') or 'SW' ('support worker') with a numeric tag.

\section{References}

Arrigo B and Milovanovic D (2009) Revolution in Penology: Rethinking the Society of Captives. Lanham, Maryland: Rowman and Littlefield.

Brumann C (2004) Comment on James P. Boggs 'The Culture Concept as Theory, in Context'. Current Anthropology 45(2): 199.

Eagleton T (2000) The Idea of Culture. Oxford: Blackwell Publishing.

Ferrell, J (1999) Cultural Criminology. Annual Review of Sociology 25: pp. 395-418.

Ferrell J, Hayward K and Young J (2008) Cultural Criminology. London: Sage.

Foucault M (1979) Discipline and Punish: The Birth of the Prison. Harmondsworth, UK: Penguin Books.

Garland D (2006) Concepts of Culture in the Sociology of Punishment. Theoretical Criminology,10(4): 419447.

Hayward K (2012) Five Spaces of Cultural Criminology. British Journal of Criminology 52(3): 441-462.

Hayward K and Young J (2004) Cultural Criminology: Some notes on the script. Theoretical Criminology 8(3): 259-273.

Karp D (2010) Unlocking men, unmasking masculinities: Doing men's work in prison. Journal of Men's Studies 18(1): 63-83.

Larmour P (2008) Corruption and the concept of 'Culture': Evidence from the Pacific Islands. Crime, Law, and Social Change 49: 225-239.

Liebling A and Maruna S (2005) Introduction: the effects of imprisonment revisited. In A Liebling and S Maruna (eds.) The Effects of Imprisonment. Cullompton, UK: Willan Publishing.

Miller J (2000) American Gulag. Yes Magazine Fall. Retrieved 29 April 2013 from <http://www.yesmagazine.org/issues/is-it-time-to-close-the-prisons>

O’Brien M (2005) What is cultural about Cultural Criminology? British Journal of Criminology 45(5): 599612.

Sampson R and Bean L (2006) Cultural mechanisms and killing fields. In R Peterson, L Krivo and J Hagan, (eds.) Race, Ethnicity, and Crime in America. New York: New York University Press: 8-36.

Sewell W (2004) Comment on James P. Boggs 'The Culture Concept as Theory, in Context'. Current Anthropology 45(2): 202-203.

Smith, M (2013) Taste of life beyond the bars' The Mercury, April 2. Retrieved 30 April 2013 from: <http://www.themercury.com.au/article/2013/04/23/377638_tasmania-news.html>

Swidler A (1986) Culture in action: Symbols and strategies. American Sociological Review 51(2): 273-286.

Wedeen L (2002) Conceptualizing culture: Possibilities for political science. American Political Science Review 96(4): 713-728. 


\section{University Library}

\section{- M M N E R VA A gateway to Melbourne's research publications}

Minerva Access is the Institutional Repository of The University of Melbourne

Author/s:

Johns, D

Title:

The Analytic Possibilities of 'Culture' in a Post-Prison Context

Date:

2014

Citation:

Johns, D. (2014). The Analytic Possibilities of 'Culture' in a Post-Prison Context. Crime, justice and social democracy: Proceedings of the 2nd International Conference, 2013, Volume 1, pp.92-98. Elsevier BV. https://doi.org/10.2139/ssrn.2435806.

Persistent Link:

http://hdl.handle.net/11343/252791 